\title{
SOFTWARE SUPPORT FOR THE INTEGRATED RESCUE SYSTEM
}

\author{
Martin Dzermansky \& Jakub Rak
}
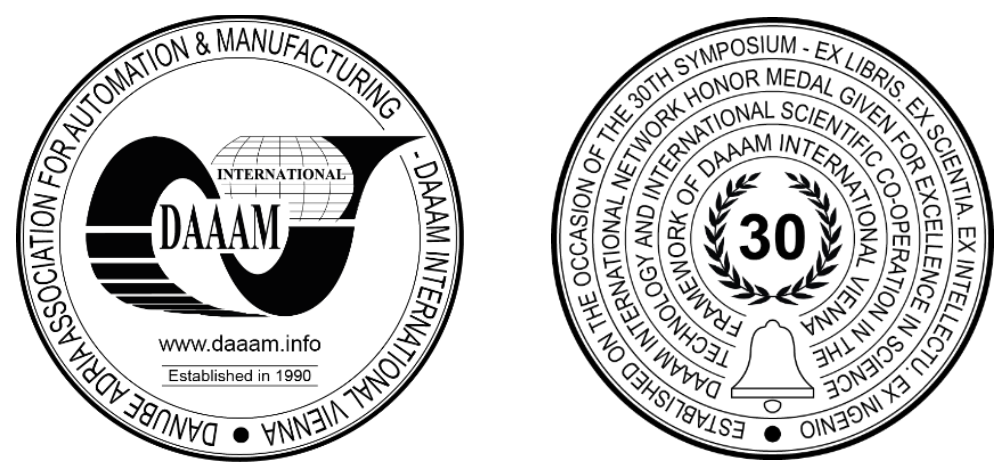

This Publication has to be referred as: Dzermansky, M[artin] \& Rak, J[akub] (2020). Software Support for the Integrated Rescue System, Proceedings of the 31st DAAAM International Symposium, pp.0860-0867, B. Katalinic (Ed.), Published by DAAAM International, ISBN 978-3-902734-29-7, ISSN 1726-9679, Vienna, Austria

DOI: $10.2507 / 31$ st.daaam.proceedings. 120

\begin{abstract}
The integrated rescue system is a coordinated approach to its components. Exercises of the integrated rescue system are needed to perform quality interventions. This paper aims to point out the possibilities of using software applications to streamline these exercises and for a better notion was created a model situation in the software applications, which can help the integrated rescue system to better create exercises and also their simulation. The paper points to the insufficient equipment of the integrated rescue system, because no software applications are used for the creation of exercises, which could make this creation more efficient.
\end{abstract}

Keywords: integrated rescue system; model; population protection; software.

\section{Introduction}

The integrated rescue system is an effective system of ties, rules of cooperation and coordination of rescue and security forces, state administration and self-government bodies, natural and legal persons in the joint implementation of rescue and liquidation work, and preparation for emergencies. Exercises of the integrated rescue system are needed to achieve quality coordination and cooperation between the components of the integrated rescue system. This work aims to point out and answer the question dealing with the issue of integrated rescue system exercises and the application of software applications to their exercises. In the Czech Republic, the issue of integrated rescue system exercises is not addressed in the literature, so this paper offers the possible applicability of software applications that could support the creation of integrated rescue system exercises. The paper describes software applications that can be used to create these exercises. Using their functions is possible to create an optimal model of exercises and individual procedures. The paper, therefore, points to the possible applications and usability of software applications in their creation and deployment in the field. The use of software applications could modernize the procedures for creating exercises for the integrated rescue system and find shortcomings in the coordination of units. [1], [2], [3], [4], [5]

\section{Integrated rescue system software}

In the Czech Republic, predetermined software is used to deal with emergencies. The reception of emergency calls is received by the operational information center, which activates the components of the integrated rescue system, and they receive as much information as possible about the emergency from the caller when the emergency occurs. 
The applications available to the dispatching center are:

- Information system Vyjezd,

- GISelIZS AE.

The first mentioned information system Vyjezd is an application for dealing with emergencies. This information system aims to ensure rescue and liquidation work at the scene. The system is managed by an operations officer, who decides on the deployment of the necessary forces and resources to deal with the emergency. The GISelIZS AE program is the basic equipment for geographic information systems of the operational centers of the fire and rescue service of the Czech Republic. It is a powerful and functionally optimized environment for working with geographic data and other data sources, whose task is to streamline the process of locating events and responding to them. [6]

\section{Possibilities of applying new software applications for creating exercises of the integrated rescue system}

The integrated rescue system uses in practice just softwares GISelIZS AE and the information system Vyjezd. However, other options would streamline the process and the possibility of creating exercises. T-SOFT's crisis management software could be another way for an integrated rescue system to improve coordination and emergency preparedness. [6]

An example will be a model situation that will be embedded in specific software applications. Specifically, it will be a traffic accident with a leak of a dangerous chemical substance. PRACTIS software is used to plan the whole exercise, and to prepare scenarios and support exercise management. It is therefore possible to create a complete scenario of integrated rescue system exercises from the notification itself to rescue and liquidation work and the end of the intervention.

The basic functions provided by the PRACTIS software include:

- processing and planning of exercises/scenarios, in structured text and graphics in real-time,

- managing of exercises,

- view the current status during the exercise,

- automatic saving of the entire exercise,

- evaluation of the created exercise and its report,

- export data to an Excel spreadsheet.

After the application loads, the start page with selected procedures and running procedures is displayed. First of all, it is necessary to create the procedure of the whole exercise and its scenario. The exercise scenario should include all the important elements that include the stages of the story, how the exercise begins, and how it will also end, and all these steps should also be timed.

A short scenario will serve as an example: [7]

- On 23 March 2020, at 10 am, an ammonia tank passed through the town of Uherske Hradiste. This tank transported liquefied ammonia in containers with a volume of 900 liters / $475 \mathrm{~kg}$ at a pressure of $0.86 \mathrm{MPa}$.

- However, when passing the main traffic light, the opposite passenger car did not give way and there was a collision with the tank.

- At 10:01 an emergency call was received at the operational and information center when the notifier reported a car accident with a tanker, during which an unknown substance also leaked. At the same time, the operation information center verified the emergency call with the notifier and made a preliminary assessment of the situation.

- At 10:02 the operational and information center notifies all integrated rescue services units.

- At 10:02, all integrated rescue system units receive notifications from the operation information center.

- At 10:04, all Integrated rescue system units travel to the scene.

- At 10:07, all integrated rescue system units arrive at the scene and immediately engage in the intervention.

After compiling the scenario, the information can be uploaded to the PRACTIS software. The user can choose between procedures, events, common documentation, and administration. After the text part of the scenario has been created, it is necessary to create a procedure in the program. It starts with the creation of a procedure, in the creation of which it is possible to add participants who will participate in this exercise or the whole group. The image below shows a list of procedures already created. In the next step, it is possible to enter information about the course of the exercise. In this step, we work with the graphic part of the project and the individual participants of the exercise are added here.

For example:

- Notifier - announcing an emergency call.

- Operational and Information Center - receiving an emergency call from the notifier, activation of Integrated rescue system units, informing about the course of the intervention, and termination.

- Ambulance service - pre-hospital emergency care, transport of the wounded to the hospital. 
- Fire and Rescue Service - organization of the place of intervention, rescue, and liquidation work, stopping the leakage of hazardous chemicals.

- Police of the Czech Republic - investigation of a traffic accident, contacting the operator, requesting the support of the city police.

- City police - closing the scene of an accident, warning, and notifying the population.

- Crisis management - warning and monitoring the development of the situation.

- Population - compliance with the order of the police.

Each participant is assigned a role according to the scenario. These roles can be linked through links that may be purely informative, in which case they are represented by an intermittent link. Once we have completed the entire graphic design of the exercise, we can already see what the whole course will look like. However, it is still necessary to add time intervals and a description of individual events.

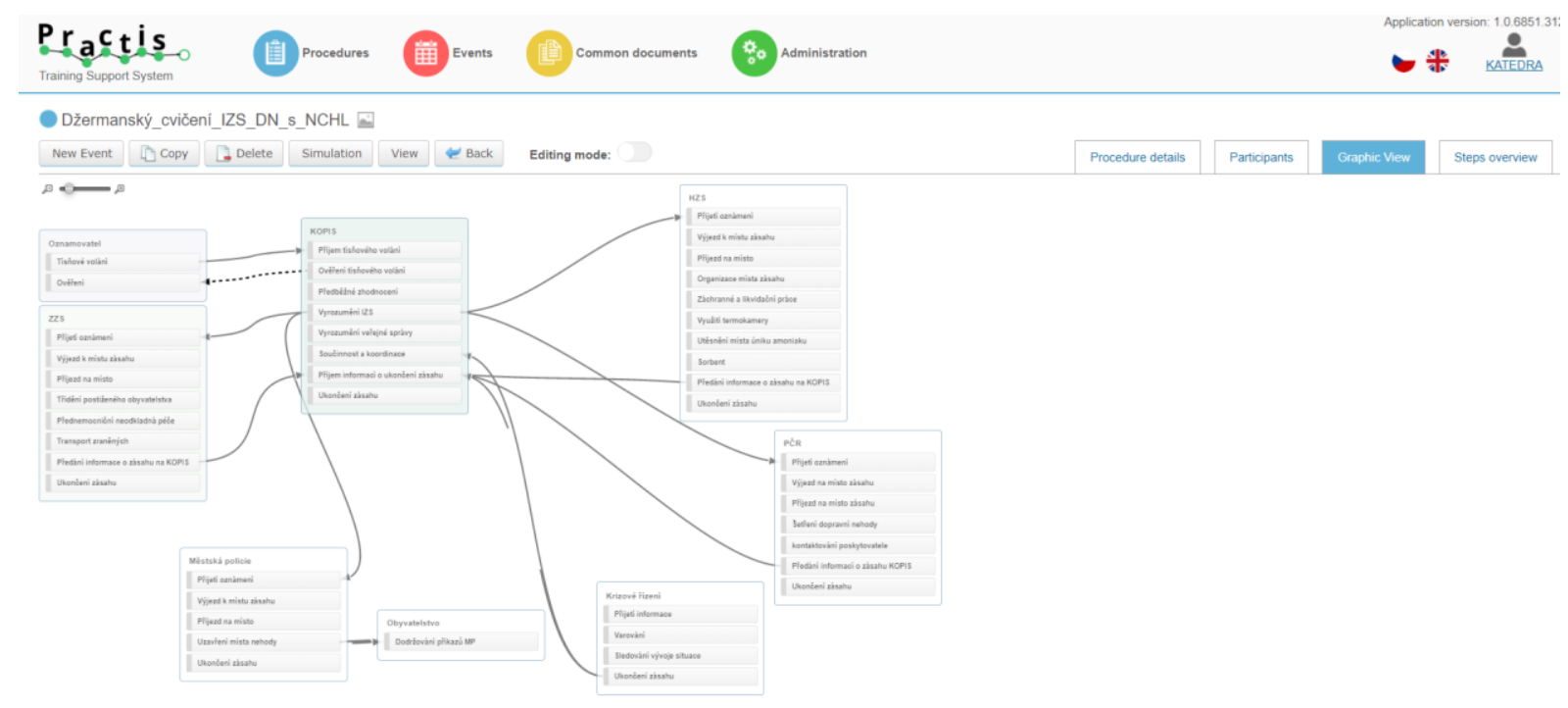

Fig. 1. Graphic design of exercise

Each event is assigned a date and the exact start time and length. Thanks to these data, the whole exercise can be simulated at intervals at which it should be completed. After completing the scenario, it is possible to create a finished exercise that can be simulated thanks to the inserted time intervals. The exercise created in this way can help individual integrated rescue system units to better coordinate and streamline the intervention.

The second program that can be used to support integrated rescue system exercises is program TerEx. Terex software can also be used in combination with PRACTIS software. Both programs can be linked and create exercise procedures and accident modeling. SW Terex is a tool designed for immediate estimation of the consequences of accidents involving the release of dangerous chemical substances, or military or terrorist attacks, in which explosive systems or chemical weapons were used, and includes a comprehensive database of hazardous chemicals containing the necessary basic as well as advanced information about each substance. Chemical and physical properties, chemical labeling, first aid recommendations, in case of contact with this substance, principles of protection and its decontamination are given here. Creating a simulation in Terex is starting with creating an event. In the beginning, it is necessary to select the emergency model and the substance. The emergency model characterizes the type of leak, if it is, for example, a one-time leak of boiling liquid with rapid evaporation into the cloud or a booby-trapped explosive system. [8]

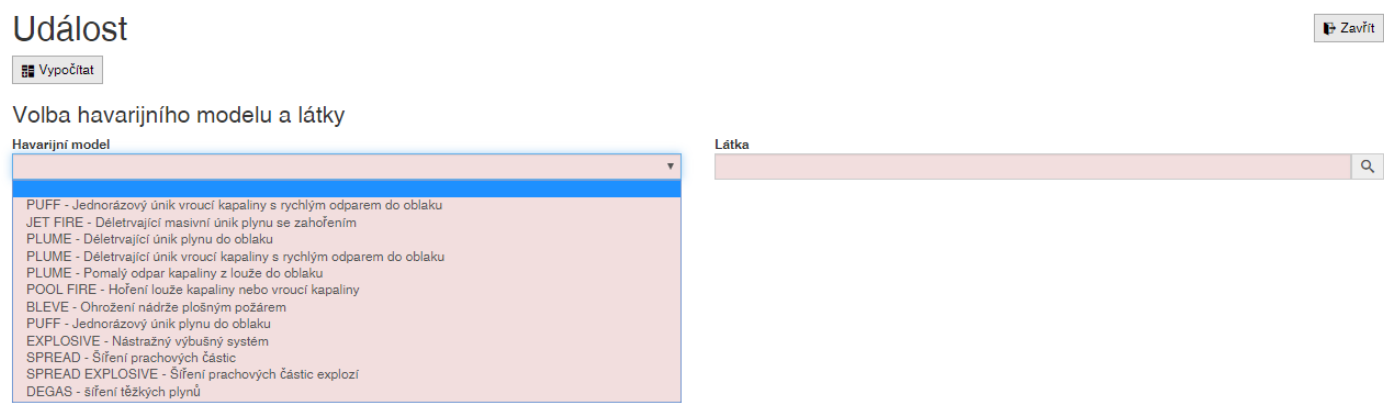

Fig. 2. Emergency model 
There is possible to enter what substance it is in the event of an accident and use the filters to make an offer. In this case, it is liquefied ammonia. However, the offer also offers nitrogen trifluoride (gas) or nitrogen trifluoride (liquid).

\section{Událost}

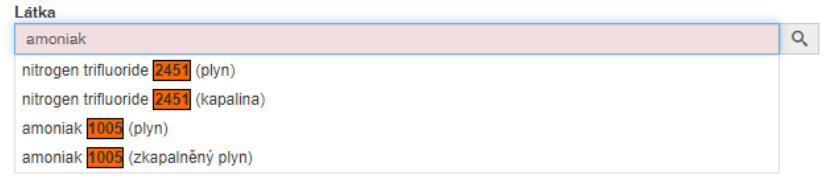

Fig. 3. Hazardous substance

After selecting the emergency model and substance, new options will be opened. Namely the parameters of the emergency model. The leaked amount of the substance in kilograms, wind speed, cloud cover, time of formation, and terrain surface are stated here. All these parameters are important for the most detailed quantification of the simulation.

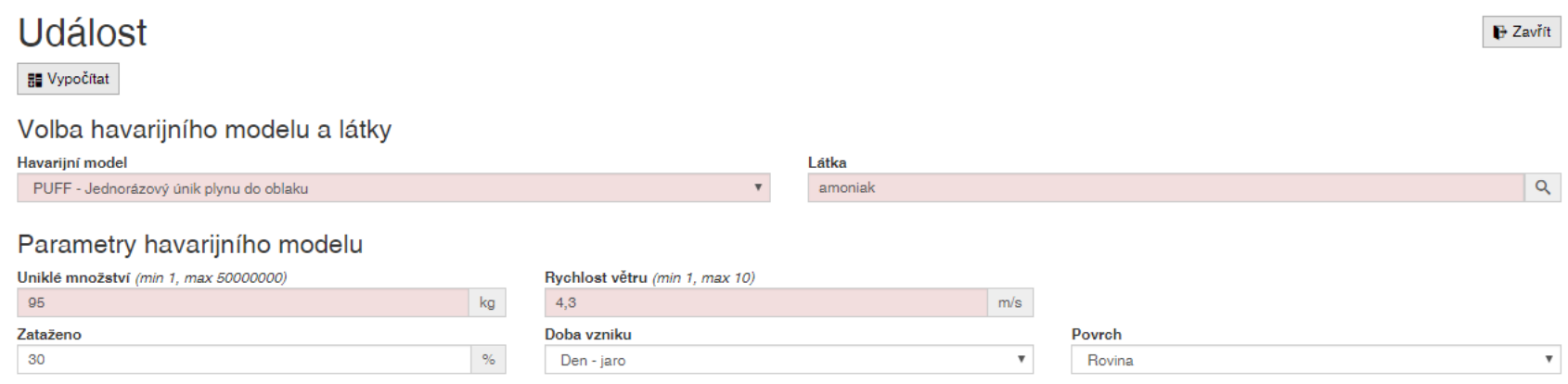

Fig. 4. Emergency model parameters

After calculating the parameters, we will see the necessary evacuation of the population. These results include these information about needed evacuation from the point of the accident:

- Danger to persons from toxic substances - $303 \mathrm{~m}$.

- Recommended survey of the toxic concentration at a distance from the leak site - $464 \mathrm{~m}$.

- Danger to persons by the direct blowing of the cloud - $36 \mathrm{~m}$.

- Danger to persons outside the building from serious injuries - $86 \mathrm{~m}$.

- Serious injuries to buildings - $64 \mathrm{~m}$.

- Danger to people inside buildings through window glass - $137 \mathrm{~m}$.

All these data are important for integrated rescue system units. They can connect them with the PRACTIS software and make the whole exercise more efficient. Once all the circumstances of the accident have been identified, mainly what type and quantity of the substance are involved, this model can be developed to help the units estimate the necessary evacuation of the population and what damage may or may have occurred. There is also a table marked as „Track type“. Two circles with a central triangle indicating the wind direction and the point of the epicenter are highlighted here.

The table shows the critical elements:

- Recommended survey of toxic concentration to a distance from the site of leakage - $454 \mathrm{~m}$.

- Danger to people inside buildings through window glass - $137 \mathrm{~m}$.

- Danger to persons by the direct blowing of the cloud - $36 \mathrm{~m}$.

- Danger to persons from toxic substances - $303 \mathrm{~m}$.

The most important information for integrated rescue system units is information about the necessary evacuation. In this case, it is an evacuation to a distance of $303 \mathrm{~m}$. So the units now know that they have to evacuate the population within a radius of $303 \mathrm{~m}$ to prevent people from coming into contact with the substance and to be safe. This information can also be reflected in exercises or scenarios in PRACTIS. 


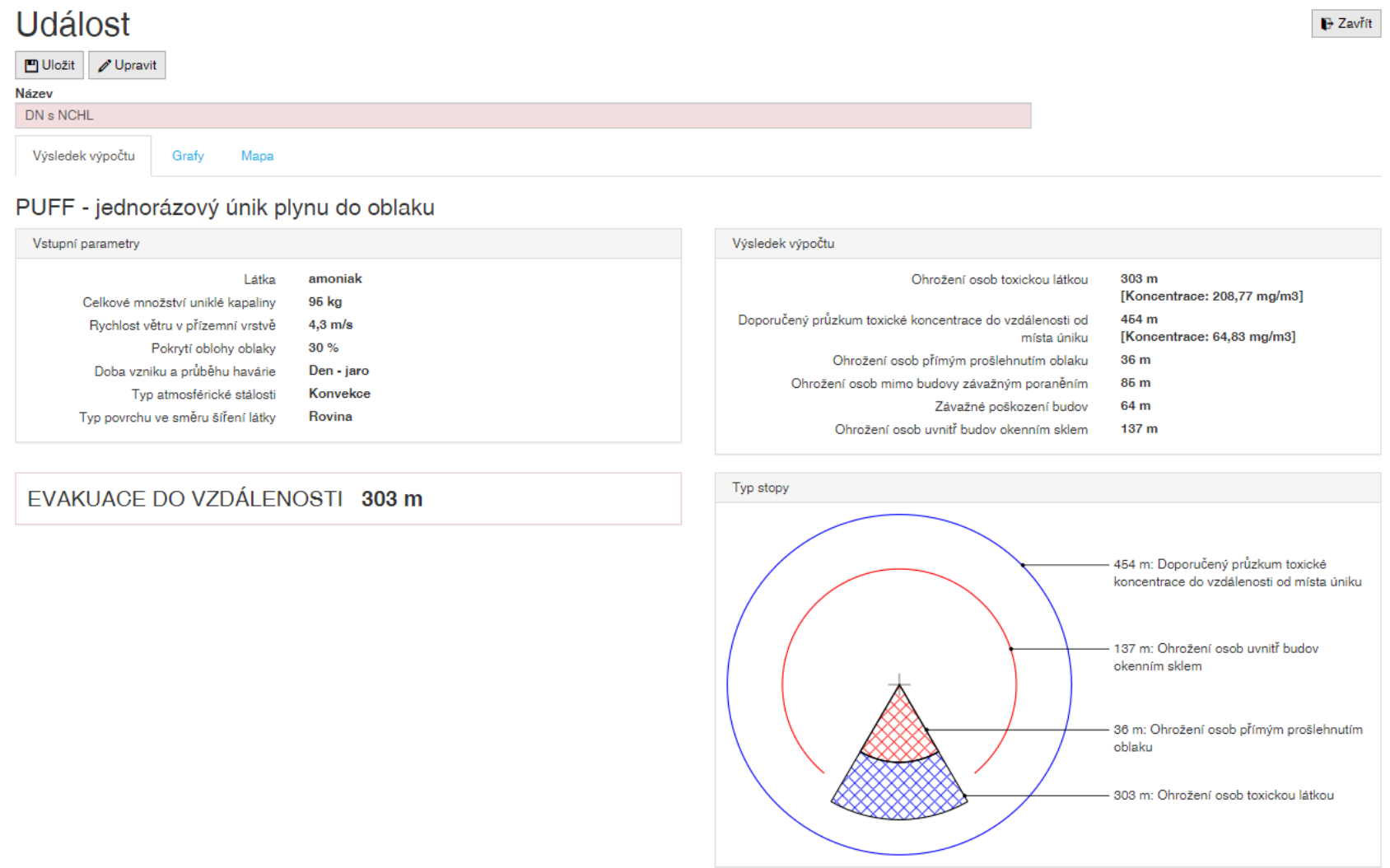

Fig. 5. The result of the calculation and simulation

The result of the calculation is also the resulting graph. In this case, it is a graph - Toxic concentration survey recommended for the distance at which the concentration of the substance falls below the IDLH value. Thus, 2 concentrations can be observed here. The first concentration is shown by the red line and is the Concentration [kg / $\mathrm{m} 3$ ] and the second concentration is shown by the yellow line and is the IDLH (Immediately Dangerous to Life or Health) concentration.

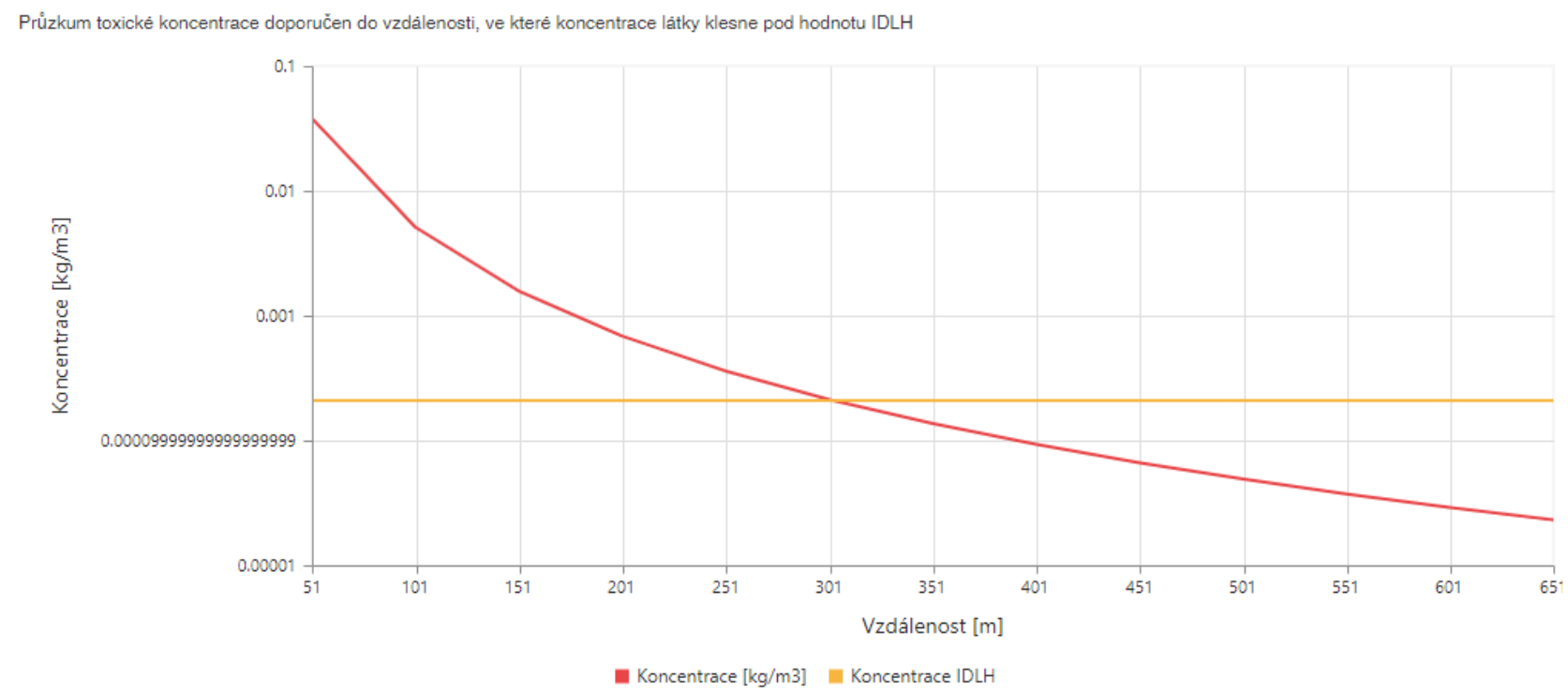

Fig. 6. Graph of the recommended exploration

In the second graph, the area of possible explosion can be observed. The graph indicates that an explosion can occur within the HMV (Upper Explosion Limit) and DMV (Lower Explosion Limit) concentrations. The graph shows 3 lines. The red line indicates the concentration [ $\mathrm{kg} / \mathrm{m} 3]$, the yellow line indicates the concentration of DMV (Lower Explosion Limit) and the last blue line indicates the concentration of HMV (Upper Explosion Limit). 


\section{Oblast moz̄ného výbuchu}

K vỹbuchu múże dojit v mezich koncentraci HMV a DMV

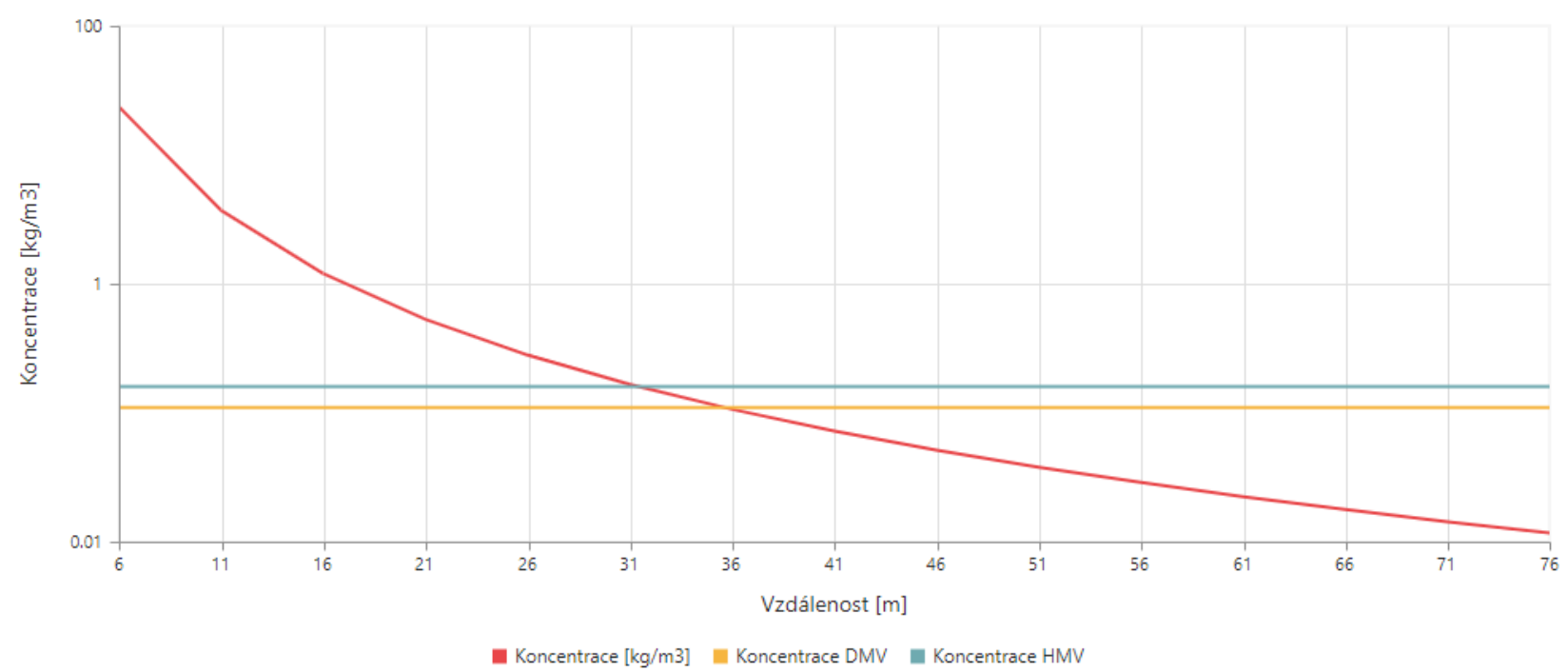

Fig. 7. Graph indicating the area of a possible explosion

The last graph shows the risk of explosion, and four lines. The first, red line indicates the shock wave overpressure $[\mathrm{kPa}]$, the yellow line indicates serious damage to the building, the blue line indicates the danger of serious injury to persons outside the building, and the last green line indicates the danger of persons inside buildings through window glass.

\section{Ohrożeni vỹbuchem}

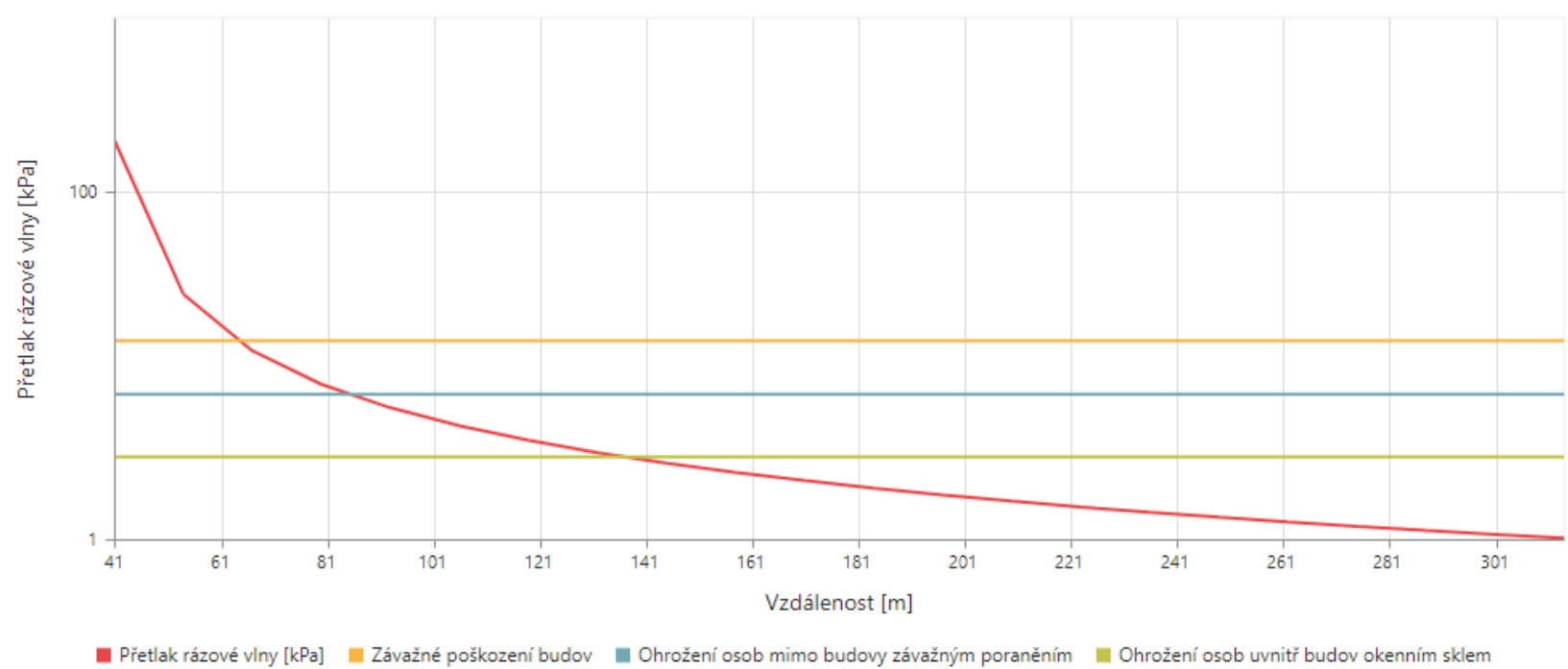

Fig. 8. Explosion hazard graph

As a result, a map is created showing the necessary evacuation and wind direction. Two circles are recorded here, blue and red. The blue circle represents the recommended survey of the toxic concentration in the distance from the leak and the red circle represents the danger of persons with a toxic substance. With the help of this map integrated rescue system units can find out how large a circle of the city needs to be evacuated and ensure the safety of the inhabitants. The direction of the wind can be set in the shooter, which is in the upper right corner. It is marked in a circle by a dark blue triangle. This map can be connected to the PRACTIS software as part of the exercise, for a better visual idea and clarification of the terrain. After calculating the necessary evacuation, it is also possible to estimate the necessary available forces and means for evacuating the population and securing the terrain. 


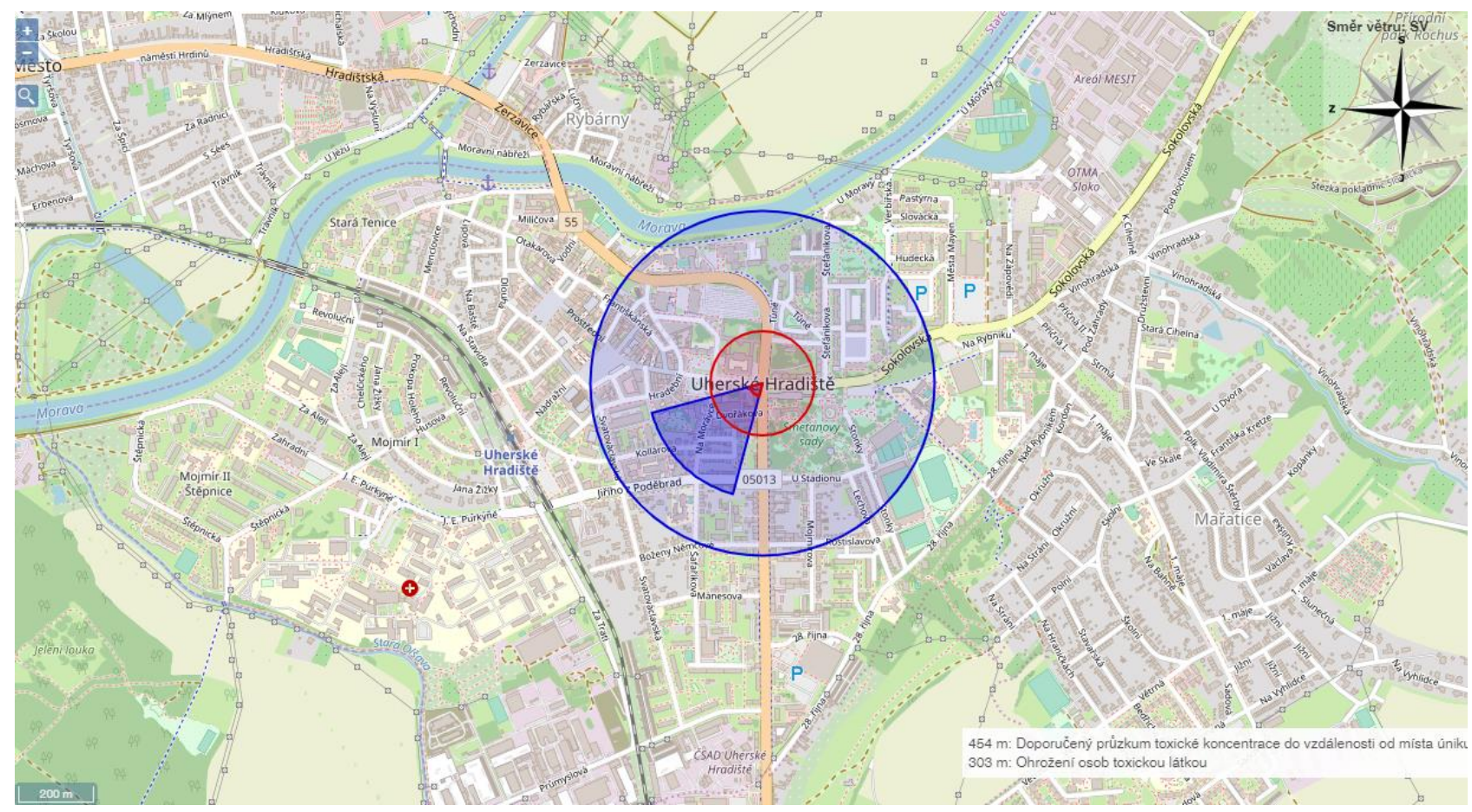

Fig. 9. The result of the evacuation

\section{Methods}

In this paper is used method of modelling. This method was used for a demonstration of the possible application of software applications for the integrated rescue system. The model can be described as image of reality. Modeling means the application of various types of models to solve a given problem. The TerEx program used models to display the consequences of an accident with the release of a dangerous chemical substance. For this paper was created a model of traffic accident with a leakage of a dangerous chemical substance. [9], [10] In addition to the modeling method, the paper also uses the method of questioning. Findings in the work were consulting with members of the integrated rescue system.

\section{Conclusion}

This paper describes the possible use of applications to support the exercises of the integrated rescue system. Integrated rescue system exercises are important for preparing for emergencies and achieve a quality of coordination and cooperation between the components of the integrated rescue system. With the help of software applications, the activity and coordinated procedures of all participants in the integrated rescue system can be streamlined. Software PRACTIS and TerEx could improve the whole process of making exercises and their simulation. These programs can perfectly help to create exercise scenarios, where can be created their links and view of all participants who occur in the accident zone. In this way, it is also possible to create time intervals, which can be used to determine the time of arrival and determine the time required for the entire intervention.

For a better demonstration of the use of the software was in this paper created a short model situation of a traffic accident with a leak of dangerous substance. In the Czech Republic is not created any literature about the problem of software support for the integrated rescue system and their exercises. The paper describes software applications that can be used and applied in the creation of exercises, their simulations, and in practice. Thus, the paper offers the possible applicability of these software applications and offers the possibility of researching other possible applications that could be used for further performance of the integrated rescue system.

\section{Acknowledgments}

This research was supported by the Internal Grant Agency of Tomas Bata University under the project No. IGA/FAI/2020/002, and also by the Institutional Support Research Program of Tomas Bata University in Zlín:Applied Informatics in Population Protection - RVO/FLK ̌̌/2020/04.

\section{References}

[1] Šenovský, M,; Adamec, V. \& Hanuška, Z. (2007). Integrovaný záchranný systém, ISBN 978-80-7385-134-7, Sdružení požárního a bezpečnostního inženýrství 
[2] Skalská, K.; Hanuška, Z. \& Dubský, M. (2010). Integrated rescue system and fire protection: modul I, ISBN 978 80-86640-59-4, MV - generální ředitelství Hasičského záchranného sboru ČR

[3] Kratochvílová, D.; Kratochvílová, D. \& Folwarczny, L. (2013). Ochrana obyvatelstva, ISBN 978-80-7385-134-7, Sdružení požárního a bezpečnostního inženýrství

[4] Hradil, J.; Mika, J. O.; Musil, M.; Svoboda, B.; Rak, J. \& Vičar, D. (2018). Základy ochrany obyvatelstva v České republice, ISBN 978-80-7454-774-4, Bezpečnost společnosti

[5] Law. Czech Republic. § 17 zákona č. 239/2000 Sb., o integrovaném záchranném systému a o změně některých zákonů. In: Zákony pro lidi.cz [online]. (C) AION CS 2010-2020 [cit. 15. 9. 2020]. Dostupné z: https://www.zakonyprolidi.cz/cs/2000-239\#p1

[6] Lukáš, L. (2011). Informační podpora integrovaného záchranného systému, ISBN 978-80-7385-105-7, Sdružení požárního a bezpečnostního inženýrství

[7] T-SOFT (2017). PRACTIS - Process optimization, Available from: http://www.tsoft.cz/optimalizace-procesu/

[8] T-SOFT (2017). TerEx - Terrorist Expert, Available from: https://www.tsoft.cz/teroristicky-expert/

[9] Lorenc. M (2013). Final work - methodology, Available from: https://lorenc.info/zaverecne-prace

[10] Blahova, M[arta]; Mach, V[aclav]; Pavlik, L[ukas]; Hromada, M[artin] \& Ficek, M[artin] (2019). The Information Security to Software of Crisis Management, Proceedings of the 30th DAAAM International Symposium, pp.10191025, B. Katalinic (Ed.), Published by DAAAM International, ISBN 978-3-902734- 22-8, ISSN 1726-9679, Vienna, Austria 